\title{
Purification and partial amino acid sequence of propionicin PLG-1, a bacteriocin produced by Propionibacterium thoenii P127 1
}

\author{
HD Paik, BA Glatz*
}

Department of Food Science and Human Nutrition, lowa State University, Ames, lowa, USA

\begin{abstract}
Summary - Propionicin PLG-1, a bacteriocin produced by Propionibacterium thoenii P127, was purified to homogeneity by ammonium sulfate precipitation followed by ion exchange column chromatography and reversed-phase high-performance liquid chromatography. According to amino acid composition analysis, propionicin PLG-1 has a calculated molecular weight of 9328 and contains 99 amino acid residues, of which $42 \%$ are hydrophobic (Ala, Ile, Leu, $\mathrm{Val}$ and Pro). A 10-amino acid sequence from the $\mathrm{N}$-terminal end was identified: $\mathrm{NH}_{2}{ }^{-1} \mathrm{Asn}-{ }^{2} \mathrm{Val}-{ }^{3} \mathrm{Asp}-{ }^{4} \mathrm{Ala}(\mathrm{Thr})-{ }^{5} \mathrm{Arg}-6 \mathrm{Thr}(\mathrm{Cys}){ }^{-7} \mathrm{Ala}(\mathrm{Thr})-{ }^{-} \mathrm{Arg}-$ ${ }^{9} \mathrm{Thr}$ (Ala)-10Pro. No homology of this sequence to sequences of other bacteriocins from lactic acid bacteria was seen in a search of the SWISS-PROT data bank.
\end{abstract}

\section{bacteriocin / propionibacteria / propionicin / composition / purification}

Résumé - Purification et séquence partielle des acides aminés de la propionicine PLG-1, une bactériocine produite par Propionibacterium thoenii P127. La propionicine PLG-1, une bactériocine produite par Propionibacterium thoenii $P 127$, a été purifiée jusqu'à homogénéité par précipitation au sulfate d'ammonium suivie d'une chromatographie sur colonne d'échange d'ions et d'une chromatographie liquide haute-performance en phase inverse. D'après l'analyse de la composition en acides aminés, la propionicine PLG-1 a un poids moléculaire calculé de 9328 et contient 99 résidus d'acides aminés, dont $42 \%$ sont hydrophobes (Ala, Ile, Leu, Val et Pro). Une séquence de 10 acides aminés de la partie $\mathrm{N}$-terminale a été identifiée : $\mathrm{NH}_{2}{ }^{-1} \mathrm{Asn}-{ }^{2} \mathrm{Val}-{ }^{3} \mathrm{Asp}-{ }^{-4} \mathrm{Ala}(\mathrm{Thr})-{ }^{5} \mathrm{Arg}-{ }^{6} \mathrm{Thr}(\mathrm{Cys}){ }^{7} \mathrm{Ala}(\mathrm{Thr})-{ }^{8} \mathrm{Arg}$ ${ }_{9}^{9}$ Thr(Ala)-10Pro. Aucune homologie de séquence avec d'autres bactériocines de bactéries lactiques n'a été trouvée en consultant la base de données SWISS-PROT.

bactériocine / bactérie propionique / propionicine / séquence d'acides aminés / purification

1 Journal paper no J-16306 of the lowa Agriculture and Home Economics Experiment Station, Ames, lowa, project no 3129.

* Correspondence and reprints: 2312 Food Sciences Bldg, lowa State University, Ames, IA 50011, USA 


\section{INTRODUCTION}

Bacteriocins are defined as bactericidal proteins with a narrow spectrum of activity targeted toward species related to the producer culture (Tagg et al, 1976). Because bacteriocins are natural products of many microorganisms associated with foods, there is currently much interest in their use as natural food preservatives.

Numerous bacteriocins from gram-positive bacteria, particularly from lactic acid bacteria, have been identified (Klaenhammer, 1988), but only a few bacteriocins have been found in propionibacteria. Among the dairy propionibacteria, 2 bacteriocins have been reported: propionicin PLG-1 from $P$ thoenii P127 (Lyon and Glatz, 1991,1993) and jenseniin G from P jensenii P126 (Grinstead and Barefoot, 1992). Propionicin PLG-1 is active against a variety of microorganisms (Lyon and Glatz, 1991) and has been shown to have a molecular weight of 10000 after purification by ion exchange chromatography and isoelectric focusing (Lyon and Glatz, 1993).

Recently, many bacteriocins have been purified to homogeneity, and the amino acid sequences of many of these purified bacteriocins have been determined. Because bacteriocins are usually extracellular products, the first purification step concentrates the bacteriocin from the culture supernatants, usually by ammonium sulfate precipitation. Several chromatographic methods, such as gel filtration, ion exchange and/or hydrophobic interaction chromatography, have been recommended to achieve significant further purification. Reversedphase chromatography was used as the final purification step for several bacteriocins, including pediocin PA-1 (Lozano et al, 1992), curvacin A (Tichaczek et al, 1992), sakacin A (Holck et al, 1992), plantaricin A (Nissen-Meyer et al, 1993), bavaricin A (Larsen et al, 1993) and piscicolin 61 (Holck et al, 1994).
Separation on reversed-phase supports in high-performance liquid chromatography (HPLC) has also been used to obtain highly purified preparations of leucocin A-UAL 187 (Hastings et al, 1991), lactacin F (Muriana and Klaenhammer, 1991), mesentericin Y105 (Hechard et al, 1992), lacticin 481 (Piard et al, 1992), salivaricin A (Ross et al, 1993), curvaticin FS47 (Garver and Muriana, 1994) and staphylococcin 1580 (Sahl, 1994). The hydrophobic nature of these bacteriocins allows their purification by reversed-phase HPLC.

The goal of this study was the determination of amino acid composition and partial sequence of propionicin PLG-1. For such a study, highly purified bacteriocin was needed. This article reports an improved procedure for purification of propionicin PLG1 , as well as its amino acid composition and $\mathrm{N}$-terminal amino acid sequence.

\section{MATERIALS AND METHODS}

\section{Bacterial cultures and media}

Producer strain Propionibacterium thoenii P127 was maintained as described previously by Lyon and Glatz (1991). Working cultures were propagated in sodium lactate broth (NLB) without shaking at $32^{\circ} \mathrm{C}$. Lactobacillus delbrueckii ATCC 4797 was obtained from Dr S Barefoot (Clemson University, Clemson, SC). Stock cultures were maintained at $-60^{\circ} \mathrm{C}$ in Lactobacilli MRS broth (Difco, Detroit, MI) containing 20\% glycerol. Working cultures were prepared from stock cultures and grown in Lactobacilli MRS broth without shaking at $37^{\circ} \mathrm{C}$.

\section{Production of propionicin PLG-1}

Strain P127 was grown in $14 \mathrm{I}$ of NLB under controlled conditions in a 19 I fermenter (model NLF22, Bioengineering AG, Wald, Switzerland) in the lowa State University Fermentation Facility. The fermentation was started with a $1 \%(\mathrm{v} / \mathrm{v})$ 
inoculum of an $18 \mathrm{~h}$ culture in NLB, and was incubated for $14 \mathrm{~d}$ at $32^{\circ} \mathrm{C}$. Agitation was at $100 \mathrm{rpm}$ without aeration. The $\mathrm{pH}$ was controlled at $7.0 \pm$ 0.1 by the addition of $3 \mathrm{~mol} / \mathrm{HCl}$ or $3 \mathrm{~mol} / \mathrm{NaOH}$.

\section{Ammonium sulfate precipitation}

The procedure reported by Lyon and Glatz (1993) was modified as follows: Ammonium sulfate was added slowly, with constant stirring, to culture supernatants $(\sim 1150 \mathrm{ml})$ to $75 \%$ saturation at $4^{\circ} \mathrm{C}$ over approximately a $10 \mathrm{~h}$ period. Slow stirring was continued for an additional $3 \mathrm{~h}$. Precipitated proteins were pelleted by centrifugation at $24000 \times g$ for $30 \mathrm{~min}$ at $4^{\circ} \mathrm{C}$, resuspended in $20 \mathrm{mmol} / \mathrm{I} 2-\mathrm{N}$-morpholino-ethane-sulfonic acid (MES; Sigma Chemical Co, St Louis, MO) buffer, $\mathrm{pH} 6.5,+0.1 \%$ Tween 80 , and dialyzed against $3 \mathrm{I}$ of $10 \mathrm{mmol} / \mathrm{l}$ MES buffer, $\mathrm{pH} 6.5,+0.1 \%$ Tween 80 , for $12-18 \mathrm{~h}$ in Spectra-Por no 3 dialysis tubing (molecular mass cutoff, 3500 ; Spectrum Medical Industries, Los Angeles, CA).

\section{Dialysis against polyethylene glycol}

When reduction of sample volume was required, the sample in dialysis tubing was placed in a weighboat containing about $50 \mathrm{~g}$ of polyethylene glycol (PEG; Mr 15 000-20 000; Sigma Chemical Co, St Louis, MO) and incubated for $1-3 \mathrm{~h}$ at $4^{\circ} \mathrm{C}$.

\section{Ion exchange chromatography}

The procedure reported by Lyon and Glatz (1993) was modified as follows: The column dimensions were $1.6 \times 23 \mathrm{~cm}$ and the bed volume of the carboxymethyl Sepharose (Sigma) was $39 \mathrm{ml}$. The column was equilibrated with $20 \mathrm{mmol} / \mathrm{IMES}$ buffer $(\mathrm{pH} 6.5)+0.1 \%$ Tween 80 and concentrated partially purified bacteriocin was applied in a descending mode at $4^{\circ} \mathrm{C}$. The column was washed with several volumes of the same loading buffer to separate unadsorbed proteins and then adsorbed proteins were eluted from the column by means of a linear salt gradient ( 0 to $1.0 \mathrm{~mol} / \mathrm{l}$ $\mathrm{NaCl}, 500 \mathrm{ml})$ in MES buffer $(\mathrm{pH} 6.5)+0.1 \%$ Tween 80 . Fractions $(4.2 \mathrm{ml}$ ) were monitored for protein content by absorbance at $280 \mathrm{~nm}$ and assayed for bacteriocin activity.

\section{Reversed-phase high-performance liquid chromatography}

Samples $(20 \mu \mathrm{l})$ were applied to a $30 \mathrm{~cm} \mu \mathrm{B}$ ondapak $C_{18}$ column (Supelcosil LC-18; Supelco, Inc, Bellefonte, PA), which was equilibrated with $0.1 \%(\mathrm{v} / \mathrm{v})$ trifluoroacetic acid (TFA; Sigma), in a Shimadzu HPLC (model LC-600, Shimadzu Corporation, Kyoto, Japan). Elution was with a $90 \mathrm{~min}$ linear gradient from $100 \%$ buffer $A$ to $100 \%$ buffer $B$, then 20 min at $100 \%$ buffer $B$. Buffer A was $0.1 \%(v / v)$ TFA in water; buffer $B$ was $0.1 \%$ TFA in 100\% 2-propanol (Fisher Scientific, Fair Lawn, $\mathrm{NJ}$ ). The flow rate was maintained at $0.4 \mathrm{ml} / \mathrm{min}$ and the eluate was monitored at $220 \mathrm{~nm}$ by means of a Shimadzu UV-Vis Spectrophotometer (model SPD-6AV, Shimadzu Corporation). Fractions of $2 \mathrm{ml}$ volume were collected and assayed for bacteriocin activity.

\section{SDS-PAGE}

Aliquots $(3-5 \mu \mathrm{l})$ of fractions obtained from HPLC were subjected to SDS-PAGE. Approximately 50-75 ng protein were loaded into each lane. Electrophoresis was performed using 10-20\% gradient polyacrylamide gels (Mini-PROTEAN II Ready Gels; Bio-Rad Laboratories, Hercules, CA), with the buffer system described by Laemmli (1970) at constant voltage (100 V) for $100 \mathrm{~min}$. Gels were fixed in $30 \%$ ethanol-10\% glacial acetic acid solution for $1 \mathrm{~h}$ and silver stained according to the manufacturer's instructions (Bio-Rad).

\section{Protein determination}

Protein content of samples at the different purification steps was determined by the bicinchoninic acid (BCA) assay (Stoscheck, 1990) according to the manufacturer's specifications (Pierce Chemical Co, Rockford, IL). Bovine serum albumin (BSA; Sigma) was used as the protein standard. Enhanced protocol, which involved color development at $60^{\circ} \mathrm{C}$ for $30 \mathrm{~min}$, was used. 


\section{Amino acid composition and sequence analysis}

Amino acid composition and sequence analysis of purified propionicin PLG-1 were performed in the lowa State University Protein Facility. Amino acid analysis was performed with an amino acid analyzer model 420A (Perkin-Elmer, Applied Biosystems Div, Foster City, CA) equipped with an integrated hydrolysis system. The amino acid sequence was determined by Edman degradation (Edman and Begg, 1967) using an Applied Biosystems 477A protein sequencer (Perkin-Elmer, Applied Biosystems Div) with an on-line $120 \mathrm{~A}$ phenylthiohydantoin amino acid analyzer.

The sequence was compared to those in the SWISS-PROT data base, by using the Sequence Analysis Software Package, licensed from the Genetics Computer Group (University of Wisconsin, Madison, WI) (Devereux et al, 1984).

\section{Bacteriocin assay}

The well diffusion assay as described by Lyon and Glatz (1993) was modified as follows: The basal layer of NLA contained 2.5\% agar and $0.1 \%$ Tween 80 and was $5 \mathrm{~mm}$ deep. After pouring the agar layer, plates were incubated $24 \mathrm{~h}$ at room temperature before wells were cut. After $7 \mathrm{~mm}$ diameter wells were cut, plates were incubated at $37^{\circ} \mathrm{C}$ for $2 \mathrm{~h}$ or at room temperature for $2 \mathrm{~d}$ to dry the plates and to facilitate sample diffusion into the agar. Indicator strain was $L$ delbrueckii ATCC 4797 , which was added to $5 \mathrm{ml}$ soft agar ( $0.7 \%$ agar) overlays of MRS medium at about $10^{7}$ cells per overlay. Serially diluted samples $(200 \mu l)$ were added to wells, allowed to diffuse at $4^{\circ} \mathrm{C}$, and the base agar was flipped into the Petri dish lid before the overlay was applied. Plates were incubated anaerobically in the BBL GasPak system (Becton Dickinson, Cockeysville, MD) for $12 \mathrm{~h}$ at $37^{\circ} \mathrm{C}$ before diameters of zones of inhibition were measured. Minimum detectable zone diameter was $9 \mathrm{~mm}$ ( $1 \mathrm{~mm}$ beyond well diameter). Activity units (AU) per $\mathrm{ml}$ of original culture were calculated from the reciprocal of the highest dilution that produced a detectable zone of inhibition. If the inhibition zone at this dilution was large (>11 mm diameter), additional incremental dilutions were assayed to define the titer more precisely.

\section{RESULTS}

\section{Purification of bacteriocin}

Propionicin PLG-1 was previously purified to homogeneity by ammonium sulfate precipitation, ion exchange chromatography and isoelectric focusing (Lyon and Glatz, 1993). To obtain highly purified preparations for amino acid composition and sequence analysis, the previously reported purification scheme was followed but was modified as required. Some changes in ammonium sulfate precipitation conditions and ion exchange chromatography were made. Reversed-phase HPLC replaced isoelectric focusing as the final step.

The purification steps and their associated recoveries of propionicin PLG-1 are given in table I. Propionicin PLG-1 was purified from the supernatant fraction of cultures grown in semidefined medium, sodium lactate broth, to minimize the presence of contaminating proteins. In preliminary studies, some bacteriocin activity was detected in the proteins precipitated at $50 \%$ saturation of ammonium sulfate. Therefore, to avoid loss of bacteriocin, a single precipitation at $75 \%$ saturation of ammonium sulfate was used.

Upon consideration of the amount of protein to be applied to the ion exchange Carboxymethyl Sepharose column and the bed volume that could accomodate this amount, a smaller column $(1.6 \times 23 \mathrm{~cm}, 39 \mathrm{ml}$ bed volume) was used than in previous work (Lyon and Glatz, 1993). After application of the bacteriocin preparation, the column was washed with MES buffer. A large protein peak was eluted within the first $63 \mathrm{ml}$ (15 fractions) of buffer (fig 1). This peak of unadsorbed proteins was completely separated from a protein peak eluted at about 0.04 to $0.16 \mathrm{~mol} / \mathrm{l} \mathrm{NaCl}$. A small portion at the tail of this peak contained $60 \%$ of the bacteriocin activity originally applied to the column. 
Table I. Purification of propionicin PLG-1.

Purification de la propionicine PLG-1.

\begin{tabular}{|c|c|c|c|c|c|c|c|c|}
\hline Sample after given step & $\begin{array}{l}\text { Volume } \\
(\mathrm{ml})\end{array}$ & $\begin{array}{l}\text { Propionicin } \\
\text { activity } \\
\text { (AU/ml) }\end{array}$ & $\begin{array}{l}\text { Total propionicin } \\
\text { activity }(A U)^{a} \text { a }\end{array}$ & $\begin{array}{l}\text { Protein } \\
\text { concentration } \\
(\mathrm{mg} / \mathrm{ml})^{b}\end{array}$ & $\begin{array}{l}\text { Total } \\
\text { protein } \\
\text { (mg) }\end{array}$ & $\begin{array}{l}\text { Sp activity } \\
(A \cup / m g)\end{array}$ & $\begin{array}{l}\text { Activity } \\
\text { recovered } \\
\text { (\%) }\end{array}$ & $\begin{array}{l}\text { Fold } \\
\text { purification }\end{array}$ \\
\hline Culture supernatant & 1150 & 2.5 & 2875 & 3.36 & 3864 & 0.74 & 100 & 1 \\
\hline $\begin{array}{l}\text { Ammonium sulfate } \\
\text { precipitation and PEG } \\
\text { concentration }\end{array}$ & 2.7 & 2560 & 6912 & 10.77 & 29.08 & 237.69 & 240.4 & 321 \\
\hline Ion exchange & 21 & 217 & 4557 & 0.2114 & 4.44 & 1026.4 & 158.5 & 1387 \\
\hline $\begin{array}{l}\text { lon exchange and PEG } \\
\text { concentration } c\end{array}$ & 0.4 & 11393 & 4557 & 11.10 & 4.44 & 1026.4 & 158.5 & 1387 \\
\hline Injection onto HPLCd & $20 \mu \mathrm{l}$ & 11393 & 227.86 & 11.10 & 0.2220 & 1026.4 & 158.5 & 1387 \\
\hline $\mathrm{C}_{18}$ reversed-phase HPLC & 8 & 25 & 200 & 0.0134 & 0.1072 & 1865.7 & 139.1 & 2521 \\
\hline
\end{tabular}

a Bacteriocin activity was determined by the well-diffusion assay. ${ }^{b}$ Protein concentration was determined by $B C A$ method. ${ }^{c}$ Volume of active samples from ion exchange column reduced from 21 to $0.4 \mathrm{ml}$ by PEG concentration. All values for ion exchange were recalculated based on this volume change. ${ }^{d}$ Only $20 \mu l$ of concentrated sample applied to high-performance liquid chromatography (HPLC). All values were recalculated based on this volume.

a Activité de la bactériocine déterminée par la méthode de diffusion radiale. ${ }^{b}$ Concentration en protéines déterminée par la méthode BCA. ${ }^{c}$ Volume d'échantillon actif provenant de la colonne d'échange d'ions réduit de $21 \mathrm{ml}$ à $0,4 \mathrm{ml}$ par concentration au PEG. Toutes les valeurs pour l'échange d'ions ont été recalculées en se basant sur ce changement en volume. ${ }^{d}$ Injection de seulement $20 \mu$ / d'échantillon concentré. Toutes les valeurs ont été recalculées en se basant sur ce volume. 


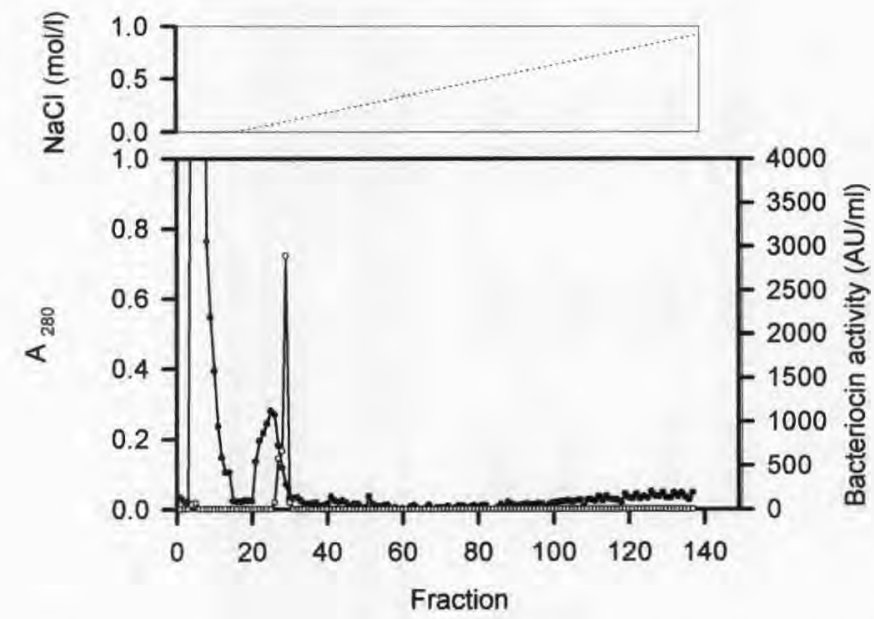

Fig 1. Elution profile of propionicin PLG-1 in CM-Sepharose column chromatography.

$\mathrm{A}_{280}$, O bacteriocin activity.

Profil d'élution de la propionicine PLG-1 au cours de la chromatographie sur colonne carboxyméthyl sepharose. - $A_{280}, O$ Activité de la bactériocine.
The previously reported final step in propionicin purification was by isoelectric focusing (Lyon and Glatz, 1993). However, despite several attempts with different combinations of ampholytes, we were not able to obtain a single protein band after isoelectric focusing. Therefore, reversed-phase HPLC was tried as an alternative method. Reversed-phase HPLC can be used for purification and/or large-scale preparation of proteins that are stable in organic mobile phases, or proteins that can renature after unfolding occurs during the elution process (Chicz and Regnier, 1990). A number of bacteriocins have been purified by this method.

Various acids and organic solvents used in reversed-phase HPLC were first tested for their effect on propionicin activity. Equal volumes of partially purified bacteriocin and methanol, 2-propanol, acetonitrile, ethanol, $0.2 \%(\mathrm{v} / \mathrm{v})$ trifluoroacetic acid (TFA) and $2 \%$ (v/v) phosphoric acid were incubated for $2 \mathrm{~h}$, then assayed for bacteriocin activity in the well diffusion assay. No effect of any of these solvents and acids on measured activity was seen, nor did the solvents and acids inhibit the indicator strain. The TFA and 2propanol were selected for use because of their excellent solubilizing properties (Chicz and Regnier, 1990).

The 5 fractions from the ion exchange column containing bacteriocin activity ( 21 $\mathrm{ml}$ total volume) were pooled, reduced to $0.4 \mathrm{ml}$ volume by dialysis against PEG to concentrate the bacteriocin, and $20 \mu \mathrm{l}$ of this concentrate were applied to an analytical $\mathrm{C}_{18}$ reversed-phase HPLC column. A preparative scale column would be preferred when large quantities of purified protein are desired, but the column used in this study was sufficient to produce enough protein for subsequent composition and sequence analyses. The elution of the propionicin preparation from the $\mathrm{C}_{18}$ column was monitored at $A_{220}$. Two independent trials were performed, and gave similar results. One trial is shown in figure 2. Several small, sharp peaks were seen, but bacteriocin activity was detected only in 10 fractions, with highest activity seen in 4 fractions containing a single peak that eluted with $84 \% 2$ propanol. A total of 56 fractions were obtained from the column. When the purity of the fractions containing bacteriocin activity was assessed by SDS-PAGE, a single protein band with apparent molecular weight 9690 was detected in 4 fractions with high 
Fig 2. $C_{18}$ reversedphase HPLC analysis of propionicin PLG-1 obtained from ion exchange chromatography. Bacteriocin activity.

Analyse par chromatographie RP-HPLC (colonne $C_{18}$ ) de la propionicine PLG-1 obtenue par chromatographie d'échange d'ions. Activité de la bactériocine.

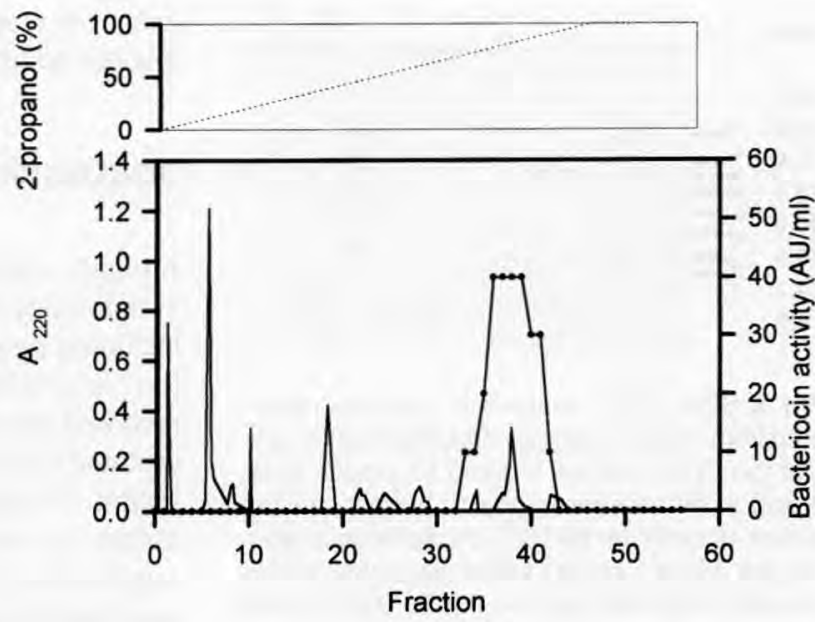

bacteriocin activity (fig 3 ). The other fractions contained this band plus possibly an additional faint band. We concluded that the $9690 \mathrm{Mr}$ protein purified at this step is propionicin PLG-1.

\section{Amino acid composition and sequence}

The amino acid composition of purified propionicin PLG-1 is given in table II. Propionicin PLG-1 contains 99 amino acid residues with a calculated molecular weight of 9328 . This agrees closely with the molecular weight of 9690 , determined by the position of propionicin PLG-1 compared to molecular weight markers in $10-20 \%$ gradient gels in SDS-PAGE (fig 3). Neutral (Gly) and hydrophobic (Ala, Ile, Leu, Val and Pro) residues make up a significant portion of propionicin PLG-1: 20 and 42\%, respectively. It should be noted that tryptophan can be destroyed by the acid hydrolysis method employed. If propionicin PLG-1 contained some tryptophan residues, they could go undetected.

The sequence of the first $10 \mathrm{~N}$-terminal amino acids was determined as follows: $\mathrm{NH}_{2}{ }^{-1}$ Asn-2 $\mathrm{Val}-{ }^{3} \mathrm{Asp}-{ }^{-4} \mathrm{Ala}$ (Thr) ${ }^{-5} \mathrm{Arg}-$
${ }^{6} \mathrm{Thr}$ (Cys)- ${ }^{7} \mathrm{Ala}$ (Thr)- ${ }^{8} \mathrm{Arg}-{ }^{-} \mathrm{Thr}(\mathrm{Ala})-{ }^{-10}$ Pro. When an amino acid is listed in parentheses after another, this indicates that either may be present, with the first being more likely. This amino acid sequence was compared

Table II. Amino acid composition of propionicin PLG-1.

Composition en acides aminés de la propionicine PLG-1.

Amino acid Mole \% $\begin{gathered}\text { Residues } \\ \text { permolecule }\end{gathered}$

$\begin{array}{lrr}\text { Alanine (Ala) } & 23.79 & 24 \\ \text { Arginine (Arg) } & 6.27 & 6 \\ \text { Aspartic acid (Asp) } & 6.91 & 7 \\ \text { Glutamic acid (Glu) } & 4.37 & 4 \\ \text { Glycine (Gly) } & 20.26 & 20 \\ \text { Isoleucine (Ile) } & 11.75 & 12 \\ \text { Leucine (Leu) } & 2.84 & 3 \\ \text { Lysine (Lys) } & 3.85 & 4 \\ \text { Proline (Pro) } & 1.21 & 1 \\ \text { Serine (Ser) } & 5.95 & 6 \\ \text { Threonine (Thr) } & 4.11 & 4 \\ \text { Tyrosine (Tyr) } & 3.15 & 3 \\ \text { Valine (Val) } & 4.77 & 5 \\ & & \\ \text { Total no of amino acids } & & 99\end{array}$

Total no of amino acids 


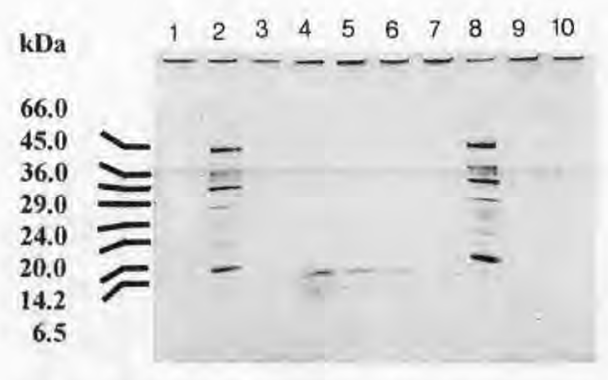

Fig 3. SDS-PAGE analysis of fractions recovered from reversed-phase HPLC that contain propionicin PLG-1. Lanes 1, 3 and 10: empty; lanes 2 and 8: Mr standards (top to bottom, bovine serum albumin [Mr 66 000], chicken egg ovalbumin [Mr 45000 ], rabbit muscle glyceraldehyde-3phosphate dehydrogenase [ $\mathrm{Mr} 36000]$, bovine erythrocytes carbonic anhydrase [Mr 29 000], bovine pancreas trypsinogen [Mr 24000$]$, soybean trypsin inhibitor [Mr 20000 ], bovine milk $\alpha$ lactalbumin [Mr 14 200], bovine lung aprotinin [Mr 6 500]; lanes 4, 5, 6, 7 and 9: HPLC fractions $33,34,35,36$ and 37 , respectively).

Analyse par SDS-PAGE de fractions obtenues par chromatographie RP-HPLC qui contiennent la propionicine PLG-1. Puits 1, 3 et 10 : vide; puits 2 et 8 : standards de poids moléculaire (de haut en bas : sérum albumine bovine [Mr 66 000], ovalbumine d'œuf de poule [Mr 45 000], glycéraldéhyde-3-phosphate déshydrogénase de muscle de lapin [Mr 36 000], anhydrase carbonique d'érythrocytes bovins [Mr 29 000], trypsinogène de pancréas bovin [Mr 24 000], inhibiteur trypsique de soja [Mr 20000$]$, $\alpha$-lactalbumine bovine [Mr 14200$]$, apoprotine de poumon bovin [Mr 6 500]; puits 4, 5, 6, 7 et 9: fractions HPLC $33,34,35,36$ et 37 , respectivement.

to others listed in the SWISS-PROT data bank. No homology to other listed proteins, including other bacteriocins from lactic acid bacteria, was found. Therefore, propionicin PLG-1 seems to be different from other previously reported bacteriocins from lactic acid bacteria.

Purified propionicin PLG-1 obtained from reversed-phase HPLC was stable to storage in the lyophilized state at both 4 and $-60^{\circ} \mathrm{C}$ for 3 months. No significant change in activity was seen in samples stored over this period (data not shown).

\section{DISCUSSION}

A highly purified bacteriocin was obtained in this study through a sequence of steps including ammonium sulfate precipitation, ion exchange chromatography and reversed-phase HPLC. Bacteriocin was precipitated from more than $1 \mathrm{I}$ of culture supernatant. The addition of so much ammonium sulfate to such large volumes of culture supernatant took over $10 \mathrm{~h}$; the samples were further stirred slowly at $4^{\circ} \mathrm{C}$ for an additional $3 \mathrm{~h}$. This much longer incubation with ammonium sulfate compared to that used previously with smaller $(50-100 \mathrm{ml})$ supernatants (usually $3 \mathrm{~h}$ to add salt plus an additional 30 min of stirring after salt addition) seemed to improve bacteriocin recovery. For example, in 1 batch, the measured activity in a $50 \mathrm{ml}$ sample was 2.4-fold lower than that measured in a 1 I sample. Possibly the longer incubation facilitates interaction of bacteriocin molecules with each other or with other proteins that can then precipitate. Other bacteriocins have been reported to precipitate poorly. For example, lactacin $\mathrm{F}$ (Muriana and Klaenhammer, 1991) and lactocin S (Mortvedt et al, 1991) have been reported to be lost as a floating fraction during ammonium sulfate precipitation, possibly due to their hydrophobic character. Slow addition of ammonium sulfate plus continued stirring for at least $3 \mathrm{~h}$ are recommended for bacteriocin recovery.

A single-step ammonium sulfate precipitation at $75 \%$ saturation was used, rather than taking the proteins precipitated between 50 and $75 \%$ saturation, because we observed that some bacteriocin activity was lost in the proteins precipitated at $50 \%$ saturation. However, this change affected the amount of protein present in the precipitate and the fold purification of bacteriocin 
obtained. In the current study, an estimated 321-fold purification was obtained after ammonium sulfate precipitation. This compares to a 600 -fold purification in this step reported previously (Lyon and Glatz, 1993).

For ion exchange chromatography, a small column with a correspondingly small bed volume was used. Bacteriocin was eluted from the column in a tight band, and was completely separated from unadsorbed proteins. However, the elution profile from the ion exchange column indicated that propionicin was not completely separated from other absorbed proteins. Therefore, a final step was necessary for complete purification. Reversed-phase HPLC proved to be an effective final step.

Recently, reversed-phase HPLC has been used to obtain highly purified preparations of a number of other bacteriocins, including leucocin A-UAL 187 (Hastings et al, 1991), lactacin F (Muriana and Klaenhammer, 1991), mesentericin Y105 (Hechard et al, 1992), lacticin 481 (Piard et al, 1992), salivaricin A (Ross et al, 1993), curvaticin FS47 (Garver and Muriana, 1994) and staphylococcin 1580 (Sahl, 1994). The hydrophobic nature of these bacteriocins, and the apparent hydrophobicity of propionicin PLG-1, allows their purification by reversed-phase HPLC. Hydrophobicity may also contribute to the tendency of many bacteriocins from lactic acid bacteria to associate with other substances to form large macromolecular complexes. For instance, lactacin B (Barefoot and Klaenhammer, 1984), helveticin J (Joerger and Klaenhammer, 1986) and lactacin F (Muriana and Klaenhammer, 1991) have been shown to form associations with lipid and carbohydrate. Bacteriocins from Lactobacillus $\mathrm{sp}$ have been reported to associate with protein-detergent (Tween 80 in MRS broth) micelles (Garver and Muriana, 1994). Association of propionicin PLG-1 with other proteins or aggregation of several molecules of propionicin into multimeric forms is the probable reason it is seen to elute in gel filtration at apparent molecular weights of more than 150000 and approximately 10000 , while under dissociating conditions it elutes at 10000 (Lyon and Glatz, 1993). As has been demonstrated most completely for the bacteriocins nisin and subtilin (Montville and Kaiser, 1993), the hydrophobicity of these molecules promotes interaction with cell membranes, leading to bactericidal action through the formation of pores in the membranes.

The successful determination of the amino acid composition and the $\mathrm{N}$-terminal sequence of propionicin PLG-1 indicates that propionicin does not contain unusual or modified amino acids, as is the case with lantibiotics such as nisin, nor does it have a blocked $\mathrm{N}$-terminus. It does contain a relatively high percentage of hydrophobic amino acids; such hydrophobicity is common among bacteriocins of lactic acid bacteria (Garver and Muriana, 1994). For example, about $50 \%$ of the amino acids are hydrophobic in lactococcin A (Holo et al, 1991), lactocin S (Mortvedt et al, 1991) and curvaticin FS47 (Garver and Muriana, 1994). However, curvacin $P$ and sakacin P (Tichaczek et al, 1992) contain only about 20-25\% hydrophobic residues. The high proportion of glycine residues in propionicin should provide a significant amount of flexibility to the molecule (Garver and Muriana, 1994). Glycine occupies very little space and allows a wide range of conformations in the folding of polypeptide chains (Stryer, 1988),

Propionicin PLG-1 was not found to share homology with other proteins (including other bacteriocins) listed in the SWISS-PROT data bank. In contrast to this result, many bacteriocins of lactic acid bacteria have been reported to share significant degrees of homology. For example, bavaricin A (Larsen et al, 1993) was found to share $66 \%$ homology with pediocin PA-1 produced by Pediococcus acidilactici (Marugg et al, 1992) and $39 \%$ homology with leucocin A-UAL 
(Hastings et al, 1991). Sakacin A (Holck et al, 1992) was reported to share some homology, especially in the $\mathrm{N}$-terminal region, with the newly sequenced bacteriocins leucocin A-UAL187 (Hastings et al, 1991), pediocin PA-1 (Lozano et al, 1992) and sakacin $P$ (Tichaczek et al, 1992). The amino acid sequence of leucocin B-Ta11a (Felix et al, 1994) was reported to be significantly homologous to the sequence of leucocin A-UAL187 (Hastings et al, 1991). A bacteriocin produced by Pediococcus acidilactici was shown to have the identical primary amino acid sequence as pediocin PA1 (Henderson et al, 1992) and was, in fact, the same molecule. Staphylococcin 1580 (Sahl, 1994) was shown to be identical to epidermin, a lantibiotic, by amino acid composition analysis, determination of molecular weight and limited $\mathrm{N}$-terminal sequencing.

In conclusion, we have obtained a highly purified preparation of propionicin PLG-1 by sequential steps of ammonium sulfate precipitation, ion exchange chromatography and reversed-phase HPLC. The amino acid sequence of propionicin PLG-1 indicates that it is different from other previously reported bacteriocins from lactic acid bacteria. Its hydrophobic nature lends support to the suggestion that propionicin PLG-1, like other bacteriocins, interacts with and may have as its primary target the cytoplasmic membrane of sensitive organisms.

\section{ACKNOWLEDGMENTS}

We are indebted to $\mathrm{Dr} E$ Hammond who provided use of his HPLC, Dr A Myers who provided access to the SWISS-PROT data base through the Sequence Analysis Software Package, the lowa State University Protein Facility for amino acid composition and sequence analysis and the lowa State University Fermentation Facility for use of fermentation equipment. This work was supported by the Binational Agricultural Research and Development Fund (BARD), grant no US2080-91.

\section{REFERENCES}

Barefoot SF, Klaenhammer TR (1984) Purification and characterization of the Lactobacillus acidophilus bacteriocin lactacin B. Antimicrob Agents Chemother 26, 328-334

Chicz RM, Regnier FE (1990) High-performance liquid chromatography: effective protein purification by various chromatographic modes. In: Guide to Protein Purification (MP Deutscher, ed) Academic Press, San Diego, CA

Devereux J, Haeberli P, Smithies O (1984) A comprehensive set of sequence analysis programs for the VAX. Nucleic Acids Res 12, 387-395

Edman P, Begg G (1967) A protein sequenator. Eur J Biochem 1, 80-81

Felix JV, Papathanasopoulos MA, Smith AA, Holy AV. Hastings JW (1994) Characterization of leucocin BTa11a: a bacteriocin from Leuconostoc carnosum Ta1 1a isolated from meat. Curr Microbiol 29, 207-212

Garver KI, Muriana PM (1994) Purification and partial amino acid sequence of curvaticin FS47, a heat-stable bacteriocin produced by Lactobacillus curvatus FS47. Appl Environ Microbiol 60, 2191-2195

Grinstead DA, Barefoot SF (1992) Jenseniin G, a heatstable bacteriocin produced by Propionibacterium jensenii P126. Appl Environ Microbiol 58, 215-220

Hastings JW, Sailer M, Johnson K, Roy KL, Vederas JC, Stiles ME (1991) Characterization of leucocin A-UAL 187 and cloning of the bacteriocin gene from Leuconostoc gelidum. J Bacteriol 173, 7491-7500

Hechard Y, Derijard B, Letellier F, Cenatiempo Y (1992) Characterization and purification of mesentericin $Y 105$, an anti-Listeria bacteriocin from Leuconostoc mesenteroides. J Gen Microbiol 138, 2725-2731

Henderson JT, Chopko AL, van Wassenaar PD (1992) Purification and primary structure of pediocin PA-1 produced by Pediococcus acidilactici PAC-1.0. Arch Biochem Biophys 295, 5-12

Holck AL, Axelsson L, Birkeland SE, Aukrust T, Blom $H$ (1992) Purification and amino acid sequence of sakacin A, a bacteriocin from Lactobacillus sake Lb706. J Gen Microbiol 138, 2715-2720

Holck AL, Axelsson L, Schillinger U (1994) Purification and cloning of piscicolin 61 , a bacteriocin from Carnobacterium piscicola LV61. Curr Microbiol 29, $63-68$

Hola H, Nilssen O, Nes IF (1991) Lactococcin A, a new bacteriocin from Lactococcus lactis subsp cremoris: isolation and characterization of the protein and its gene. J Bacteriol 173, 3879-3887

Joerger MC, Klaenhammer TR (1986) Characterization and purification of helveticin $\mathrm{J}$ and evidence for a chromosomally determined bacteriocin produced by Lactobacillus helveticus 481. J Bacteriol 167 , $439-446$ 
Klaenhammer TR (1988) Bacteriocins of lactic acid bacteria. Biochimie 70, 337-349

Laemmli UK (1970) Cleavage of structural proteins during the assembly of the head of bacteriophage T4. Nature (London) 227, 680-685

Larsen AG, Vogensen FK, Josephsen J (1993) Antimicrobial activity of lactic acid bacteria isolated from sour doughs: purification and characterization of bavaricin A, a bacteriocin produced by Lactobacillus bavaricus M1401. J Appl Bacteriol 75, 113-122

Lozano JCN, Nissen-Meyer J, Sletten K, Pelaz C, Nes IF (1992) Purification and amino acid sequence of a bacteriocin produced by Pediococcus acidilactici. $J$ Gen Microbiol 138, 1985-1990

Lyon WJ, Glatz BA (1991) Partial purification and characterization of a bacteriocin produced by Propionibacterium thoenii. Appl Environ Microbiol 57, 701-706

Lyon WJ, Glatz BA (1993) Isolation and purification of propionicin PLG-1, a bacteriocin produced by a strain of Propionibacterium thoenii. Appl Environ Microbiol $59,83-88$

Marugg JD, Gonzales CF, Kunka BS, Ledeboer AT, Pucci MJ, Toonen MY, Walker SA, Zoetmulder LCM, Vandenbergh PA (1992) Cloning, expression, and nucleotide sequence of genes involved in production of pediocin PA-1, a bacteriocin from Pediococcus acidilactici PAC1.0. Appl Environ Microbiol 58, 2360-2367

Montville TJ, Kaiser AL (1993) Antimicrobial proteins: classification, nomenclature, diversity, and relationship to bacteriocins. In: Bacteriocins of Lactic Acid Bacteria (DG Hoover, LR Steenson, eds) Academic Press, San Diego, CA

Mortvedt Cl, Nissen-Meyer J, Sletten K, Nes IF (1991) Purification and amino acid sequence of lactocin $\mathrm{S}$, a bacteriocin produced by Lactobacillus sake L45. Appl Environ Microbiol 57, 1829-1834

Muriana PM, Klaenhammer TR (1991) Purification and partial characterization of lactacin $F$, a bacteriocin produced by Lactobacillus acidophilus 11088. Appl Environ Microbiol 57, 114-121

Nissen-Meyer J, Holo H, Havarstein LS, Sletten K, Nes IF (1992) A novel lactococcal bacteriocin whose activity depends on the complementary action of two peptides. J Bacteriol 174, 5686-5692

Nissen-Meyer J, Larsen AG, Sletten K, Daeschel M, Nes IF (1993) Purification and characterization of plantaricin A, a Lactobacillus plantarum bacteriocin whose activity depends on the action of two peptides. J Gen Microbiol 139, 1503-1509

Piard JC, Muriana PM, Desmazeaud MJ, Klaenhammer TR (1992) Purification and partial characterization of lacticin 481, a lanthionine-containing bacteriocin produced by Lactococcus lactis subsp lactis CNRZ 481. Appl Environ Microbiol 58, 279-284

Ross KF, Ronson CW, Tagg JR (1993) Isolation and characterization of the lantibiotic salivaricin $A$ and its structural gene salA from Streptococcus salivarius 20P3. Appl Environ Microbiol 59, 2014-2021

Sahl H (1994) Staphylococcin 1580 is identical to the lantibiotic epidermin: implications for the nature of bacteriocins from gram-positive bacteria. Appl Environ Microbiol 60, 752-755

Stryer L (1988) Connective-tissue proteins. In: Biochemistry (L Stryer, ed) WH Freeman Co, New York, NY

Stoscheck CM (1990) Quantitation of protein. In: Guide to Protein Purification (MP Deutscher, ed) Academic Press, San Diego, CA

Tagg JR, Dajani JS, Wannamaker LW (1976) Bacteriocins of gram-positive bacteria. Bacteriol Rev 40 , 722-756

Tichaczek PS, Nissen-Meyer J, Nes IF, Vogel RF. Hammes WP (1992) Characterization of the bacteriocins curvacin $\mathrm{A}$ from Lactobacillus curvaticus LTH1174 and sakacin P from L sake LTH673. Syst Appl Microbiol 15, 460-468 